\title{
PENGARUH PELATIHAN PLYOMETRIK LOMPAT BANGKU DAN LOMPAT MELEWATI BANGKU TERHADAP DAYA LEDAK OTOT TUNGKAI
}

\author{
I Made Danu Budhiarta \\ Universitas Pendidikan Ganesha, J1 Udayana 11 Singaraja \\ e-mail: danu_tantri@yahoo.co.id
}

\begin{abstract}
The Effect of Plyometric Exercise of Jumping on Benches and Jumping over Benches on Explosive Power of Leg Muscles. This study aimed at describing (1) the quality of the explosive power of the students' leg muscles and (2) analyze the difference of explosive power of the students' leg muscles between group of students that learn using plyometric jumping on benches and plyometric jumping over benches at Physical Health and Recreation Education Departement FOK Undiskha. This type of research belonged to a quasi experimental research. The explosive power was obtained by converting the high gain scores of the vertical jump test with body weight on the basis of Lewis' nomogram scale. Then the data were analyzed using covariance analysis by SPSS program version 17.0. The result shows that, (1) the quality of the explosive power of the students' leg muscles was poor. (2) plyometric exercise of jumping on benches and jumping over benches could improve explosive power of students' leg muscles significantly, and (3) the improvement of explosive power of the students' leg muscles with plyometric jumping on benches was better than plyometric jumping over benches $(F=7.872$ dan $p=0.001<\alpha=0.05)$.
\end{abstract}

Keywords: exercise, explosive power of leg muscles, plyometric jumping on benches, plyometric jumping over benches

\begin{abstract}
Abstrak: Pengaruh Pelatihan Plyometrik Lompat Bangku dan Lompat Melewati Bangku terhadap Daya Ledak Otot Tungkai. Penelitian ini bertujuan untuk: (1) mendeskripsikan kualitas daya ledak otot tungkai mahasiswa dan (2) menganalisis perbedaan daya ledak otot tungkai antara mahasiswa yang mendapat pelatihan plyometrik lompat bangku dan lompat melewati bangku di Jurusan Penjaskesrek FOK UNDIKSHA. Jenis penelitian ini adalah penelitian kuasi eksperimen. Data daya ledak diperoleh dengan mengkonversi skor tinggi raihan dari hasil tes vertical jump dengan berat badan berdasarkan skala nomogram dari Lewis. Selanjutnya data dianalisis menggunakan analisis varians dengan program SPSS 17,0. Hasil penelitian ini adalah (1) kualitas daya ledak otot tungkai mahasiswa berada dalam kategori kurang, (2) pelatihan plyometric lompat bangku dan lompat melewati bangku sama-sama dapat meningkatkan daya ledak otot tungkai mahasiswa secara signifikan, dan (3) peningkatan daya ledak otot tungkai mahasiswa dengan pelatihan plyometrik lompat bangku (PLB) lebih besar dari pada plyometrik lompat melewati bangku (PLMB) $(\mathrm{F}=7,872$ dan $\mathrm{p}=0,001$ $<\alpha=0,05)$.
\end{abstract}

Kata-kata Kunci: daya ledak otot tungkai, pelatihan, plyometrik lompat bangku, plyometrik lompat melewati bangku

Perkembangan olahraga di Indonesia dewasa ini cukup menggembirakan. Bagi masyarakat di daerah tertentu olahraga sudah merupakan kebutuhan, hal ini terlihat dari berbagai bentuk kegiatan, antara lain berdirinya kelompok-kelompok senam aerobik, club fitness, serta olah raga dengan jalan kaki dan lari pada hari minggu pagi.
Selain itu, dapat dilihat dari ramainya penonton pada cabang-cabang olahraga tertentu seperti sepak bola, bola voli, basket dan lain-lain. Ini semua menggambarkan bahwa masyarakat sudah merasakan perlunya olahraga dilakukan baik secara individu maupun kelompok. 
Lutan (1988:28) menyatakan, ada empat dimensi yang terkandung dalam olahraga, yaitu: (1) olahraga rekreatif yang menekankan tercapainya kesehatan jasmani dan rokhani, dengan tema khas berupa pelepasan ketegangan hidup seharihari; (2) olahraga pendidikan yang menekankan aspek pendidikan dimana olahraga merupakan alat untuk mencapai tujuan pendidikan; (3) olahraga kompetitif yang menekankan pada kegiatan perlombaan dan pencapaian prestasi; dan (4) olahraga profesional yang menekankan tercapainya keuntungan material.

Dalam olahraga prestasi, kegiatan olahraga yang dilakukan sifatnya sangat kompleks, karena dipengaruhi berbagai faktor. Faktor tersebut dapat dibedakan menjadi dua yaitu: "1) faktor eksogen, seperti lingkungan fisik tempat berlatih, lingkungan keluarga yang membantu membangun ambisi atlet, dan 2) faktor endogen yakni atribut yang melekat pada atlet seperti struktur anatomi, kemampuan fisiologi, sistem persyarafan, serta ciri-ciri kepribadian yang bersangkutan" (Lutan, 1988: 28)

Salah satu faktor eksogen yang sangat menentukan keberhasilan pencapaian prestasi adalah metode pelatihan yang digunakan. Dalam hal ini pelatihan dengan metode ilmiah telah memberikan pengaruh yang kuat dalam pencapaian prestasi olahraga. Seorang pelatih harus menyadari bahwa metode pelatihan trial and error sudah bukan zamannya lagi, sudah saatnya pelatih menerapkan metode ilmiah dalam program pelatihan dengan baik dan benar yang memuat empat aspek yaitu fisik, teknik, taktik dan mental. Keempat aspek inilah yang harus dikembangkan secara maksimal dan seimbang agar atlet benar-benar memiliki kemampuan pada saat pertandingan sehingga berpeluang untuk mencapai prestasi puncak atau memenangkan pertandingan.

Seorang atlet yang telah mencapai prestasi tinggi maka kondisi fisiknya telah dalam kondisi prima. Kondisi fisik yang prima berarti telah memiliki komponen kebugaran jasmani yang baik. Sajoto (1995) menyatakan, komponen kesegaran jasmani merupakan komponen kondisi fisik, seperti: kekuatan, daya tahan, daya ledak otot, kecepatan, kelentukan, keseimbangan, koordinasi, kelincahan, ketepatan dan reaksi, sedangkan menurut Pyke (1980: 31) komponen dasar keterampilan untuk olahraga dan bermain termasuk kekuatan otot, daya tahan otot, power otot, daya tahan aerobik, keseimbangan, kelentukan, kelincahan, koordinasi mata, koordinasi tangan, dan koordinasi tubuh secara umum.
Untuk mencapai suatu prestasi, komponenkomponen di atas perlu dikembangkan dan ditingkatkan melalui suatu latihan yang teratur, terprogram dan berkelanjutan. Sebagaimana dinyatakan oleh Thorndike (dalam Abdullah, A. dan Manadji, 1994: 162) bahwa: "pelatihan yang dilakukan berulang-ulang mengakibatkan berkembangnya keterampilan yang lebih baik". Khusus untuk pelatihan daya ledak yang digunakan pada semua cabang olahraga penggunaan beban selama pelatihan juga menjadi salah satu pertimbangan pelatih. Nosek (1982: 15) menyatakan bahwa beban pelatihan untuk meningkatkan daya ledak, kekuatan dan daya tahan otot tidak harus selalu berupa beban luar yang menggunakan peralatan seperti barbel, rompi, katrol, dan lainnya, tetapi dapat pula berupa berat badan sendiri, terutama bila yang dilatih atlet pemula.

Pelatihan daya ledak umumnya difokuskan pada daya ledak otot tungkai, karena otot tungkai merupakan pusat gerakan. Daya ledak hasil gerakannya dapat dilihat berbentuk vertikal, horizontal, dan melengkung. Pada cabang-cabang olahraga bola voli (pada saat melakukan smash, block), bola basket (pada saat jump ball), sepak bola, loncat tinggi, lompat indah dan senam, gerakan daya ledaknya lebih banyak pada gerakan lompat ke atas atau vertikal. Pada olahraga lari, renang, balap sepeda dan dayung, hasil daya ledaknya horisontal. Pada olahraga ini, sulit untuk melihat kapan saat melakukan daya ledak, karena gerakan kaki atau tangan berputar secara monoton. Sedangkan pada olahraga lompat jauh, tolak peluru, lempar lembing dan lempar cakram, daya ledak menghasilkan gerakan menyerupai garis lengkung. Kemampuan daya ledak yang baik sangat menentukan seseorang untuk mencapai prestasi optimal, terutama daya ledak otot tungkai, karena otot-otot tungkai merupakan pusat gerak yang utama bagi tubuh secara keseluruhan. Jika daya ledak otot tungkai lemah tidak memungkinkan seseorang dapat mencapai prestasi optimal.

Hasil observasi peneliti di lapangan selama melakukan pembinaan prestasi pada cabang olahraga bola voli, atletik dan tenis lapangan, hampir semua mahasiswa Jurusan Penjaskesrek FOK UNDIKSHA memiliki daya ledak otot tungkai yang kurang optimal (data observasi perkuliahan bola volly di Penjaskesrek, 2010). Di sisi lain, mereka adalah calon guru pendidikan jasmani yang nantinya akan memberikan contoh gerakan kepada siswanya. Bila kondisi daya ledak otot tungkai kurang, tidak mungkin dapat member- 
kan contoh gerakan yang baik dan benar, apalagi untuk menjadi pemain yang baik dan berprestasi pada suatu cabang olahraga. Hal ini merupakan masalah yang perlu diupayakan pemecahannya, sehingga daya ledak otot tungkai mahasiswa calon guru olahraga berkualitas baik.

Untuk meningkatkan daya ledak otot tungkai dapat diberikan bermacam-macam pelatihan fisik, antara lain: lompat tali, squat jump, lompat kotak, lompat jauh tanpa awalan, lompat bangku, lompat melewati bangku, lompat dari kotak ke kotak yang lebih rendah, dan lain-lain. Dalam penelitian ini, untuk meningkatkan daya ledak otot tungkai peneliti akan memberikan pelatihan berupa plyometrik.

Plyometrik merupakan bentuk latihan untuk mendapatkan eksplosive power (KONI, 2000 : 27). Plyometrik adalah metode latihan untuk meningkatkan kekuatan dan power otot tertentu. Cara yang paling baik untuk mengembangkan power maksimal pada otot tertentu ialah dengan meregangkan (memanjangkan) dahulu otot-otot tersebut. Sebelum mengkontraksikan (memendekkan) otot-otot secara eksplosif (meledak-ledak). Dengan kata lain, kita dapat mengerahkan lebih banyak tenaga pada suatu kelompok otot, apabila kita terlebih dahulu menggerakkan otot tersebut kearah yang berlawanan. Untuk melatih power otot tungkai, mula-mula gerakkan tungkai kearah yang berlawanan (jongkok), merupakan apa yang disebut sebagai fase pra regang (prestreching phase). Kemudian melompat dengan sekuat tenaga ke atas. Setelah mendarat, tanpa adanya waktu berhenti, kemudian secepatnya melompat lagi sekuat tenaga ke atas, sehingga seakan-akan mendarat pada bara api. Oleh karena itu, untuk meingkatkan loncatan pemain bola voli, kekuatan daya ledak otot tungkai perlu dilatih dengan pelatihan plyometrik. Dalam penelitian ini pelatihan dilakukan dengan plyometrik lompat bangku (PLB) dan plyometrik lompat melewati bangku (PLMB). Namun seberapa besar pengaruh pelatihan plyometrik tersebut terhadap peningkatan daya ledak otot tungkai mahasiswa, serta metode plyometrik mana yang lebih baik digunakan, belum terungkap secara empirik.

Berdasarkan hal tersebut, tujuan dilaksanakannya penelitian ini adalah untuk (1) mendeskripsikan kualitas daya ledak otot tungkai mahasiswa, (2) membuktikan bahwa pelatihan plyometrik lompat bangku dan lompat melewati bangku berpengaruh terhadap daya ledak otot tungkai, dan (3) untuk mengetahui metoda mana yang lebih baik dalam meningkatkan daya ledak otot tungkai antara metoda plyometrik lompat bangku dan lompat melewati bangku.

Penelitian dilandasi oleh suatu teori di mana daya ledak (explosive power) merupakan unsur penting bagi seseorang agar dapat memiliki kemampuan fisik yang prima, sebab daya ledak sangat dibutuhkan untuk kegiatan fisik sehari-hari yang memerlukan tenaga eksplosif seperti lompat, loncat, lari cepat, memukul, menendang, mengangkat, melempar, dan lain-lain. Daya ledak banyak dibutuhkan dalam cabang-cabang olahraga yang predominan kontraksi otot cepat dan kuat, kedua unsur ini saling mempengaruhi. Otot yang kuat mempunyai daya ledak besar, begitu juga sebaliknya otot yang memiliki daya ledak yang besar hampir dapat dipastikan mempunyai kekuatan yang besar pula (Pyke,1980: 39).

Untuk mendapatkan daya ledak yang baik diperlukan adanya pelatihan. Pelatihan merupakan sarana untuk meningkatkan kondisi fisik, baik itu hanya untuk menjaga, meningkatkan kesegaran jasmani maupun untuk meningkatkan, mengembangkan kondisi fisik secara umum dalam rangka mencapai prestasi salah satu cabang olahraga. Pelatihan tersebut harus dilakukan secara teratur, terprogram, dan kontinu. Pelatihan adalah proses kerja yang dilakukan secara sistematis dan berkesinambungan, dimana beban dan intensitas latihan makin hari makin ditambah, sehingga pada akhirnya memberikan rangsangan secara menyeluruh terhadap tubuh dan bertujuan untuk meningkatkan kemampuan fisik serta mental secara bersama-sama (Mulyono, 1987: 2).

Pelatihan daya ledak yang sekarang ini dikembangkan adalah metode pelatihan plyometrik. Chu (1982: 3) menyatakan bahwa pelatihan plyometrik adalah pelatihan yang memungkinkan otot untuk mencapai kekuatan maksimal dalam waktu yang sesingkat mungkin. Metode pelatihan plyometrik ini sangat efektif untuk meningkatkan daya ledak. Hasil penelitian Mahfudin (2007) menemukan bahwa pelatihan plyometrik dengan beban latihan berpengaruh terhadap tinggi loncatan pemain bola voli. Sementara itu, Redcliffe dan Farentinos (1985: 83) menyatakan bahwa: pelatihan plyometrik yang dapat meningkatkan daya ledak anggota gerak bagian bawah diantaranya dapat dilakukan dengan teknik latihan lompat melambung, berjingkat-jingkat, lompatlompat baik ke atas bangku maupun melewati bangku, lompat berjingkat ke depan, melompatmeloncat, dan memantul. Sedangkan otot yang dilatih dalam pelatihan plyometrik untuk meningkatkan daya ledak otot tungkai adalah: mus- 
culus Gastrucnemius, Peroneus Longus, Soleus dan Peroneus Brevis.

Prinsip pelatihan plyometrik diawali dengan pemanasan untuk meregangkan otot rangka, ligamen dan kalestenik agar tidak terjadi cedera, kemudian dilanjutkan dengan aktivitas pelatihan yang diprogramkan. Setelah itu pelatihan ditutup dengan gerakan pendinginan. Dari berbagai bentuk pelatihan plyometrik yang dikembangkan, dalam penelitian ini dipilih pelatihan Plyometrik Lompat Bangku (PLB) dan Plyometrik Lompat Melewati Bangku (PLMB), karena kedua bentuk pelatihan plyometrik ini sangat mudah dilakukan dan memerlukan alat-alat yang sederhana.

\section{METODE}

Jenis penelitian ini adalah penelitian kuasi eksperimen karena menggunakan kelas apa adanya. Rancangan penelitian adalah Pre Test-Post Test Non Equivalent Control Group Design yaitu suatu rancangan penelitian dengan menggunakan pre test dan post test yang diberikan pada kelaskelas tidak sepadan. Subjek penelitian ini adalah mahasiswa putra semester 3 Jurusan Penjaskesrek FOK Undiksha tahun akademik 2010/2011, berjumlah 60 orang yang terdistribusi ke dalam 4 kelas. Sample diambil secara random, dimana keempat kelas itu diundi secara random untuk mendapatkan 2 kelas eksperimen dan 1 kelas kontrol dengan jumlah tiap kelas adalah 30 orang.

Kelompok eksperimen 1 (K1) merupakan kelompok eksperimen yang diberi perlakuan plyometrik lompat bangku, kelompok eksperimen 2 (K2) merupakan kelompok eksperimen yang diberi perlakuan plyometrik lompat melewati bang$\mathrm{ku}$, dan kelompok ketiga merupakan kelompok kontrol yang tidak diberi perlakuan. Kemudian dicari perbedaan nilai rata-rata hasil pengukuran dari keduanya. Perbedaan diasumsikan disebabkan oleh perlakuan. Desain penelitian ini dapat digambarkan seperti Gambar 1.

\begin{tabular}{l}
\hline $\mathrm{K} 1$ \\
$-\mathrm{K} 2$ \\
$\mathrm{~K} 3$
\end{tabular}

Gambar 1. Rancangan Penelitian (Creswell, 2010) Keterangan:

$\mathrm{K} 1=$ kelompok eksperimen 1 dengan pelatihan plyometrik lompat bangku (PLB)

$\mathrm{K} 2=$ kelompok eksperimen 2 dengan pelatihan plyometrik lompat melewati bangku (PLMB)

$\mathrm{K} 3=$ kelompok kontrol yang tidak diberi perlakuan

$\mathrm{P}=$ Pre-test untuk kelompok $1,2,3$

$\mathrm{X} 1=$ pelatihan plyometrik lompat bangku
$\mathrm{X} 2=$ pelatihan plyometrik lompat melewati bangku

$\mathrm{X} 3$ = tanpa perlakuan khusus

$\mathrm{T} 1=$ Post test $\mathrm{untuk}$ kelompok 1,2,3, dilakukan setelah pelatihan

---- garis putus-putus menyatakan bahwa dilakukan pengundian dalam pengambilan sampel secara random.

Data yang dikumpulkan adalah data daya ledak otot tungkai. Data ini dikumpulkan dengan menggunakan tes vertical jump. Selain itu, disusun juga instrumen berupa program pelatihan plyometrik berdasarkan pedoman pelatihan plyometrik. Prosedur pengambilan data penelitian adalah sebagai berikut.

1) Pengambilan data berat badan.

Data mengenai berat badan diambil pada saat melakukan pretest dan posttest. Dalam pengambilan data berat badan orang coba hanya memakai celana pendek dan kaos lengan pendek, yang diusahakan seringan mungkin sehingga tidak ada penambahan berat badan.

2) Pelaksanaan Pelatihan Plyometrik

Pelaksanaan pelatihan diawali dengan pemanasan selama 10-15 menit, terdiri dari peregangan statis dan peregangan dinamis, dilakukan secara sistematik yaitu mulai dari kepala sampai ke kaki, selanjutnya di teruskan dengan lari-lari ringan. Semuanya bertujuan untuk meningkatkan temperatur otot sehingga memperkecil terjadinya cedera pada otot, terutama otot yang berkontraksi.

Pada kelompok eksperimen I, setelah pemanasan dilanjutkan dengan pelatihan plyometric lompat bangku: posisi awal orang coba berdiri di atas bangku dengan kedua kaki rapat dan badan tegak, setelah ada aba-aba "ya" melakukan loncatan ke atas lalu turun dengan kedua kaki membuka, sehingga bangku berada diantara kedua kakinya. Setelah terasa kedua ujung kaki menyentuh lantai, maka dia harus melakukan lompat sekuat-kuatnya dan secepat-cepatnya kembali ke posisi semula di atas bangku swedia. Begitu seterusnya dalam tempo yang cepat selama 10-15 detik, istirahat 45 detik, 6-10 kali, sebanyak 4-8 set. Istirahat diantara set selama 2-5 menit, dan satu bangku dipakai oleh 4 orang. Pelatihan dilakukan hingga masuk pada zona pelatihan.

Pada kelompok eksperimen II, setelah pemanasan dilanjutkan dengan pelatihan plyometric lompat melewati bangku. Pelaksanaan pelatihan sebagai berikut. Posisi awal orang coba berdiri tegak di samping kanan atau kiri bangku Swedia dengan kedua kaki rapat, setelah aba-aba "ya", melompat ke seberang melewati bangku 
dengan kedua kaki rapat, setelah terasa ujung kaki menyentuh lantai, dengan kekuatan dan kecepatan maksimal lompat kembali ke tempat semula. Pelatihan ini dilakukan berulang-ulang dengan irama cepat selama 10-15 detik, istirahat 45 detik dengan 6-10 kali ulangan sebanyak 4-8 set, diantara set istirahat 2-5 menit. Pelatihan ini dilakukan 3 kali seminggu selama 6 minggu.

Zone pelatihan tercapai apabila denyut nadi permenitnya telah berada pada daerah $72 \%$ 87\% denyut nadi maksimal (Harsono, 1988: 116). Di mana denyut nadi maksimal $=220-$ umur masing-masing, sedangkan denyut nadi permenit dapat diperoleh dengan cara diwaktu istirahat antar set pada saat istirahat 45 detik dilakukan pengecekan denyut nadi dengan cara palpasi yaitu masing-masing memegang dengan kedua ujung jari manis dan jari tengah arteri yang ada di sebelah luar pergelangan tangan kirinya. Setelah merasakan denyut nadi masing-masing lalu diberi aba-aba "ya", setelah 15 detik diberi aba-aba stop, hasil masing-masing dikalikan empat, itulah denyut nadi permenit waktu pelatihan. Selanjutnya dibandingkan dengan zone pelatihan. Jika belum sampai pada 80\%-90\%nya disarankan untuk menambah kecepatan, bagi yang sudah masuk zone pelatihan diminta untuk tetap mempertahankannya atau naik sedikit jangan sampai turun lagi.

Pada akhir pelatihan selalu dilaksanakan kegiatan cool down atau pendinginan, yang bertujuan untuk menurunkan secara cepat laju metabolisme dan fungsi kardiorespiratori kekeadaan istirahat, sehingga mengurangi konsentrasi asam laktat yang tinggi di dalam darah maupun otot.

3) Pelaksanaan Tes Daya Ledak Otot Tungkai

Setelah melaksanakan pelatihan plyometrik, dilanjutkan dengan melaksanakan tes untuk mengukur daya ledak otot tungkai, dilakukan 2 kali yaitu sebelum pelatihan (pre-test) dam setelah pelatihan (post-test). Alat ukur yang digunakan adalah tes vertical jump dengan prosedur pelaksanaan penelitian sebagai berikut.

Sebelum melakukan tes, orang coba ditimbang terlebih dahulu, kemudian mengoleskan keempat ujung jari tangan kanan/kiri pada kapur yang tersedia, lalu mengambil sikap berdiri tegak dengan tangan lurus ke atas menghadap pada skala pengukuran yang tersedia dengan kedua kaki rapat badan dan lurus ke atas, ujung tangan ditempelkan pada papan skala, bekas kapur yang menempel pada papan skala tepat pada garis dan angka, angka tersebut dicatat dan merupakan hasil raihan tanpa loncatan.
Gerakan berikutnya orang coba menekuk lutut dengan badan membungkuk, kedua tangan ditarik ke belakang, selanjutnya mengayunkan tangan ke atas disertai loncat setinggi-tingginya, pada saat titik tertinggi tangan diluruskan ke atas dan menepukkan ujung jari yang berkapur pada papan skala, dilakukan tiga kali kesempatan, dicatat hasil loncatan yang tertinggi.

Hasil raihan dari loncatan tertinggi dikurangi dengan hasil raihan tanpa loncat merupakan hasil loncatan, yang kemudian akan dikonsultasikan dengan skala berat badan yang tersedia pada skala Nomogram Lewis. Dari skala tersebut didapatkan kemampuan daya ledak otot tungkai orang coba.

Analisis terhadap kualitas daya ledak otot tungkai mahasiswa dilakukan dengan mengkonversi nilai rata-rata daya ledak otot tungkai mahasiswa ke pedoman konversi yang telah ditetapkan, seperti pada Tabel 1.

Tabel 1. Klasifikasi Kemampuan Daya Ledak Otot Tungkai

\begin{tabular}{ccc}
\hline Putra & Putri & Klasifikasi \\
\hline$<90$ & $<60$ & Kurang sekali \\
$90-119$ & $60-89$ & Kurang \\
$120-149$ & $90-119$ & Sedang \\
$150-179$ & $120-149$ & Baik \\
$>160$ & $>150$ & Baik Sekali \\
\hline
\end{tabular}

(Sajoto, 1995: 24)

Untuk mengetahui pengaruh pelatihan plyometrik terhadap daya ledak otot tungkai, serta metode mana yang lebih baik dalam meningkatkan daya ledak otot tungkai dilakukan analisis varians. Perhitungan dilakukan dengan bantuan komputer menggunakan program SPSS (Statistical Package/Program for Social Sciences) versi 17,0 dengan taraf signifikansi 5\%. Hipotesis Ho ditolak jika nilai signifikansi $\mathrm{p}<0,05$.

\section{HASIL DAN PEMBAHASAN}

Hasil perhitungan terhadap nilai rata-rata daya ledak otot tungkai mahasiswa Penjaskesrek ditunjukkan pada Tabel 2.

Berdasarkan Tabel 2 dapat diketahui bahwa kualitas daya ledak sebelum pelatihan dari ketiga kelompok hampir mendekati sama atau seimbang, Nilai rata-rata pre test ketiga kelompok, masing-masing adalah: $\mathrm{K} 1=98,63, \mathrm{~K} 2=98,80$, $\mathrm{K} 3=97,00$ dan ketiga nilai tersebut bila dikonversi ke tabel klasifikasi daya ledak untuk putra, termasuk dalam kategori daya ledak kurang. Pada post test (setelah pelatihan) terlihat ada perbedaan nilai rata-rata dari ketiga kelompok. Per- 
bedaan tersebut sangat dimungkinkan karena perlakuan yang diberikan pada kelompok eksperimen. Hasil tes menunjukkan adanya peningkatan, nilai rata-rata post test dari masing-masing kelompok yaitu: $\mathrm{K} 1=104,23, \mathrm{~K} 2=103,10$, dan $\mathrm{K} 3=97,30$. Bila dikonversikan ke tabel klasifikasi daya ledak putra, nilai tersebut masih termasuk kategori kurang. Temuan ini menunjukkan bahwa kualitas daya ledak otot tungkai mahasiswa masih tergolong kurang, baik sebelum maupun setelah perlakuan. Rendahnya kualitas daya ledak otot tungkai mahasiswa perlu ditindaklanjuti, karena, bila daya ledak otot tung-kai bawah seseorang baik, maka ia akan memiliki kekuatan, kecepatan, dan koordinasi gerak yang baik.

Tabel 2. Nilai Rata-rata dan Standar Deviasi Daya Ledak untuk Pre Test dan Post Test

\begin{tabular}{|c|c|c|c|c|c|c|}
\hline Kelompok & $\mathrm{N}$ & Jenis test & $\begin{array}{l}\text { Total skor } \\
\text { Daya Ledak }\end{array}$ & Rata-rata & $\begin{array}{l}\text { Standar } \\
\text { deviasi }\end{array}$ & Kategori \\
\hline \multirow[t]{3}{*}{ K1 (PLB) } & 30 & Pre-test & 2959 & 98,63 & 14,53 & Kurang \\
\hline & 30 & Post-test & 3127 & 104,23 & 13,53 & Kurang \\
\hline & 30 & Gain & 168 & 5,60 & 6,86 & \\
\hline \multirow[t]{3}{*}{ K2 (PLMB) } & 30 & Pre-test & 2964 & 98,80 & 12,81 & Kurang \\
\hline & 30 & Post-test & 3093 & 103,10 & 13,58 & Kurang \\
\hline & 30 & Gain & 129 & 4,30 & 5,45 & \\
\hline \multirow[t]{3}{*}{ K3(Kontrol) } & 30 & Pre-test & 2910 & 97,00 & 10,14 & Kurang \\
\hline & 30 & Post-test & 2919 & 97,30 & 10,38 & Kurang \\
\hline & 30 & Gain & 9 & 0,30 & 3,24 & \\
\hline
\end{tabular}

Untuk mengetahui besarnya respon terhadap pelatihan dengan metode PLB dan PLMB dapat diketahui dengan menghitung rata-rata gain skor (selisih post test dan pre test) yang dicapai setiap orang coba. Hasil perhitungannya dapat dilihat pada Tabel 3.

Tabel 3. Besarnya Respon Pelatihan Setiap Kelompok

\begin{tabular}{ccc}
\hline Kelompok & $\begin{array}{c}\text { Rata-rata Gain } \\
(\Delta \overline{\mathrm{X}})\end{array}$ & $\begin{array}{c}\text { Rata-rata } \\
\text { perorang }\end{array}$ \\
\hline $\mathrm{K} 1$ (PLB) & 5,60 & 0,19 \\
\hline $\mathrm{K} 2$ (PLMB) & 4,30 & 0,14 \\
\hline $\begin{array}{c}\mathrm{K} 3 \\
\text { (Kontrol) }\end{array}$ & 0,30 & 0,01 \\
\hline
\end{tabular}

Tabel 3 menunjukkan besarnya respon pelatihan dilihat dari besarnya rata-rata peningkatan $(\Delta \bar{X})$ antara pre test dan post test masing-masing kelompok. Untuk kelompok 1 (PLB), ratarata peningkatan dari pre test ke post test sebesar 5,60 poin dengan rata-rata peningkatan perorang sebesar 0,19 poin. Kelompok 2 (PLMB) dengan kenaikan respon pelatihan dari pre test ke post test sebesar 4,30 poin dengan peningkatan ratarata perorang sebesar 0,14 poin, sedangkan kelompok 3 (Kontrol) respon pelatihan dari pre test ke post test juga mengalami peningkatan sebesar 0,30 poin dengan rata-rata peningkatan perorang 0,01 poin.

Pengujian hipotesis nol yang menyatakan "tidak terdapat perbedaan peningkatan daya ledak otot tungkai mahasiswa antara kelompok mahasiswa yang belajar dengan PLB, PLMB dan konvensional" dilakukan dengan bantuan kom- puter melalui program SPSS 17,0. Hasil perhitungan ditampilkan pada Tabel 4.

Tabel 4 dilihat dari respon pelatihan terhadap metode PLB dan PLMB yang menunjukkan adanya peningkatan (respon pelatihan perorang secara rata-rata meningkat sebesar 0,19 untuk PLB dan 0,14 untuk PLMB). Adanya peningkatan daya ledak mahasiswa menunjukkan bahwa metode plyometrik ini cukup efektif digunakan dalam pelatihan daya ledak otot tungkai, walaupun peningkatannya masih relatif kecil.

Dari Tabel 4 terlihat bahwa $\mathrm{F}$ hitung = 7,872 dengan batas penolakan $\mathrm{p}=0,001$. Oleh karena $\alpha=0,05>\mathrm{p}=0,001$ maka Ho ditolak atau rata-rata dari ketiga kelompok berbeda nyata. Dengan kata lain, terdapat perbedaan rata-rata peningkatan skor daya ledak otot tungkai mahasiswa antara $\mathrm{K} 1$ dengan $\mathrm{K} 3$, K2 dengan $\mathrm{K} 3$ dan $\mathrm{K} 1$ dengan $\mathrm{K} 2$ secara signifikan. Ini berarti, terdapat perbedaan peningkatan daya ledak otot tungkai mahasiswa antara kelompok mahasiswa yang belajar dengan PLB, PLMB dan konvensional. Dengan kata lain pelatihan dengan plyometrik lompat bangku (PLB) dan plyometrik lompat melewati bangku (PLMB) masing-masing berpengaruh terhadap peningkatan daya ledak otot tungkai mahasiswa Penjaskesrek.

Kecilnya peningkatan perolehan hasil pelatihan, bukan berarti pelatihan plyometrik tidak dapat digunakan untuk melatih daya ledak otot tungkai mahasiswa. Agar peningkatan pelatihan berarti maka pelatihan hendaknya dilakukan secara berkelanjutan yang ditunjang adanya program pelatihan yang tepat untuk mengatasi ham- 
batan-hambatan yang cenderung muncul pada saat pelatihan. Sebagaimana dinyatakan oleh Soekarman (1989: 11), bahwa untuk mengatasi hambatan dalam pelatihan perlu disusun strategi dan rencana pelatihan yang baik. Pelatihan dilakukan seminggu 3 (tiga) kali selama 2 (dua) bulan, akan memberikan efek yang cukup berarti, dapat mengembangkan daya tahan, daya ledak otot tungkai dan kelentukan bagi pemula Bompa (1994: 77).

Selain itu hasil penelitian ini juga menunjukkan bahwa hasil belajar kelompok kontrol ju-

Tabel 4. Hasil Analisis Varians ga mengalami peningkatan. Peningkatan respon pelatihan perorang secara rata-rata adalah 0,01 poin. Mengenai peningkatan yang dialami kelompok kontrol disebabkan karena orang coba telah mengikuti perkuliahan tenis lapangan secara konvensional (tradisional) yang memang muncul pada semester itu. Tetapi, bila dibandingkan respon pelatihan yang dicapai maka peningkatan respon pelatihan kelompok eksperimen 2 yang paling besar, sedangkan kelompok kontrol peningkatannya paling kecil (lihat Tabel 03).

\begin{tabular}{lrrrrr}
\hline Sumber Varians & \multicolumn{1}{c}{ Df } & JK & RK & F & P \\
\hline Antar kelompok & 457,800 & 2 & 228,900 & 7,872 & 0,001 \\
\hline Dalam kelompok & 2529,800 & 87 & 29,078 & & \\
\hline Total & 2987,600 & 89 & & & \\
\hline
\end{tabular}

Setelah diketahui bahwa rata-rata selisih pre test dan post test dari skor daya ledak otot tungkai berbeda secara signifikan, analisis dilanjutkan dengan Uji Post Hoc untuk mengetahui berapa besar derajat beda rata-rata antar kelompok. Uji post hoc dilakukan dengan uji HSD (Highly Significance Diference) yang dalam program SPSS uji HSD dianalisis menggunakan uji Tukey dengan taraf signifikansi $5 \%$. Hasil uji $\mathrm{HSD}_{0,05}$ menunjukkan bahwa perlakuan yang diberikan pada kelompok eksperimen 1 (PLB) lebih berpengaruh terhadap peningkatan daya ledak mahasiswa dari pada perlakuan yang diberikan pada kelompok eksperimen 2 (PLMB), maupun dengan pembelajaran secara konvensional. Oleh karena itu, metode pelatihan dengan plyometrik lompat bangku (PLB) lebih baik dari pada plyometrik lompat melewati bangku (PLMB) dalam meningkatkan daya ledak otot tungkai mahasiswa, sehingga PLB perlu terus dikembangkan untuk meningkatkan kualitas daya ledak otot tungkai mahasiswa dalam mendukung pengembangan tinggi loncatan pada permainan bola voli.

Kondisi disebabkan karena pada latihan naik turun bangku tumpuan dua kaki (PLB) mempunyai suatu kelebihan, yaitu adanya irama yang cepat pada waktu melakukan latihan, yaitu hitungan 1 - 2 untuk sekali loncatan, sehingga menghasilkan daya ledak oto tungkai yang lebih tinggi dan kekuatan otot kaki secara maksimum. Gerakan meloncat ke atas pada posisi badan dan kaki membentuk sudut. Sesuai dengan gerakan melayang pada waktu melakukan lompatan dalam melakukan smash, dengan demikian latihan loncat naik turun bangku dengan tumpuan dua kaki atau plyometrik loncat ke atas bangku (PLB) merupakan latihan yang berdaya guna

(efektif) dan hasil guna. Kekurangan latihan lompat melewati bangku adalah gerakan terfokus pada lompatan agar bisa melewati bangku, sehingga lompatan mahasiswa pada PLMB relatif kurang tinggi dari pada PLB. Selain itu, kecepatan irama lompatan dengan PLMB relatif lebih lambat (hitungan 1-4 untuk sekali loncatan). Lompatan yang kurang tinggi dengan irama yang lebih lambat, kurang dapat melatih ketepatan dan kekuatan tolakan. Hal ini membuat daya ledak dan kekuatan otot kaki dalam PLMB kurang maksimum.

Walaupun perbedaannya signifikan, tetapi kenaikannya relatif kecil dan belum sesuai dengan harapan. Kecilnya peningkatan daya ledak otot tungkai mahasiswa mungkin disebabkan terjadinya beberapa kendala dalam pelaksanaan penelitian yang tidak disadari oleh peneliti. Beberapa kendala yang diperkirakan menjadi penyebabnya adalah: (1) kurang terkontrolnya variabel penelitian dari kelompok kontrol dan kelompok eksperimen. Karena penelitian ini sifatnya kuasi eksperimen tentunya tidak dapat dihindarkan kelompok kontrol maupun eksperimen mendapat perkuliahan/pelatihan olahraga lainnya yang bisa memberi dampak pada peningkatan daya ledak otot tungkai mahasiswa. (2) Adanya kesalahan dalam teknik pengambilan data yang tidak disengaja, seperti kesalahan paralaks dalam pembacaan skala pada timbangan, pada tinggi raihan di dinding, dan saat mengkonversi berat dengan tinggi raihan pada skala nomogram. (3) Adanya kesalahan pengukuran sebagai akibat kaliberasi alat yang kurang tepat. (4) Ukuran sampel penelitian yang digunakan perlu diperbesar sehingga prediksi yang diperoleh untuk populasi lebih akurat. 


\section{SIMPULAN}

Dari pembahasan hasil penelitian di atas dapat disimpulkan bahwa: pertama, kualitas daya ledak otot tungkai mahasiswa Jurusan Penjaskesrek FOK Universitas Pendidikan Ganesha yang diberi pelatihan plyometrik lompat bangku dan lompat melewati bangku masih kurang memadai. Kedua, Pelatihan plyometrik lompat bangku dan

\section{DAFTAR RUJUKAN}

Abdullah, A.A. Manadji. 1994. Dasar-dasar Pendidikan Jasmani. Jakarta: Dirjen Dikti Depdikbud.

Bompa, T.O. 1994. Power Training for Sport, Plyometric for Maximum Power Development. Canada: Mosaic Press.

Chu, D.A. 1982. Jumping Into Plyometric. Champain: Leisure Press.

Crawford, M \& Roni, V. 2009. Plyometric Training for Health-Related Fitness. Health \& Fitness Journal of Canada, 1 (2): 13-16.

Harsono. 1988. Coaching dan Aspek-aspek Psikologis dalam Coaching. Jakarta: Dirjen Dikti.

KONI. 2000. Panduan Kepelatihan. Jakarta: KONI

Lutan, rusli. 1988. Belajar Keterampilan Motorik, Pengantar Teori dan Metode. Jakarta: Dirjen Dikti.

Mahfudin. A . 2007. "Pengaruh latihan Plyometrics dan Weight Training terhadap Ting- lompat melewati bangku masing-masing berpengaruh secara signifikan terhadap peningkatan daya ledak otot tungkai mahasiswa Jurusan Penjaskesrek FOK Universitas Pendidikan Ganesha, pada $\alpha=0,05$. Ketiga, pelatihan plyometrik lompat bangku (PLB) memberikan pengaruh yang lebih besar terhadap peningkatan daya ledak otot tungkai dibandingkan dengan plyometrik lompat melewati bangku (PLMB).

gi Loncatan pada Atlet Bolavoli Putri PAB Yogyakarta". Skripsi. Yogyakarta: FIK, UNY.

Mulyono. 1987. Pembinaan dan Peningkatan Kondisi Fisik. Solo: FKIP UNS.

Nossek, J. 1982. General Theory of Training. Logos: Pan African Press.

Pyke, F.S. 1980. Toward Better Coaching. Canbera, Australia: Governement Publishing Service.

Radcliffe, J.C, and Farentinos, R.C. 1985. Plyometrics. Illinois: Human Kinetics $\mathrm{Pu}-$ blisher Inc.

Sajoto, M. 1995. Peningkatan dan Pembinaan Kondisi Fisik dalam Olahraga. Jakarta: Depdikbud.

Creswell., J.W. 2010. Research Design, Qualitative, Quantitative, and Mixed Methods Approaches (third ed.). California: Sage $\mathrm{Pu}-$ blication.

Soekarman, R. 1987. Dasar-dasar Olahraga untuk Pembina, Pelatih, dan Atlet. Jakarta: Indayu Press. 